\title{
Analysis of Air and Soil Quality Regarding the Cross-Border Impact Risk of the Mining Tailings Ponds in Moldova Nouă Area
}

\author{
Simona Raischi, Eduard Pană, Elena Holban, Ștefan Zamfir, Marius Raischi, and György Deák
}

\begin{abstract}
This paper concerns to the air and soil pollution in the area of tailings ponds in Moldova Nouă, situated on Danube bank, near the Romania-Serbia border. The tailings ponds resulted from mining operations since the previous century, represent now a source of historical pollution in the area, especially on air quality, through dispersal of tailings dust on large surfaces. Depending on weather conditions, especially in case of drought periods, the wind of various intensities raises the dust and disperses it, affecting land surfaces: urban, tourist, agricultural, protected areas of community interest, like RAMSAR Iron Gates Natural Park - Divici-Pojejena Wetland. The dispersion has a direct effect on human health because of its chemical composition, which may contain $\mathrm{SiO} 2$ and heavy metals like $\mathrm{Cu}, \mathrm{Pb}, \mathrm{Cd}, \mathrm{Ni}$, etc. Results were obtained following several field measurements of dust particles concentrations at various critical points, in corroboration with laboratory analyses of their content. For the study of the pollutants dispersion, the Breeze AERMOD model was used for obtaining cross-border pollution maps, respectively of the historical pollution by the accumulation of heavy metals in the soil from the immediate vicinity of the analysed area.
\end{abstract}

Index Terms-Air pollution, air modelling, soil quality, tailings ponds.

\section{INTRODUCTION}

Mining is identified as one of the human activities with a negative impact on the environment quality, especially due to the natural ecosystems destruction, by the removal of soil, vegetation and not only [1]. Mining sites are often contaminated with several types of heavy metals, mainly from ore processing, tailings and wastewater disposal [2]. In the last 20-30 years, most of Romanian mines have been closed [3], but the historical pollution caused by tailings ponds, which served as a landfill for the waste generated during the extraction process, has remained a concern at the moment for communities in their neighbourhood [4].

The need to monitor the environmental factors in the tailings ponds area is underlined by the fact that a large proportion of people living near them are frequently exposed to pollutants concentrations, which often exceed the limits set by the European Air and Soil Quality Directives. According to the World Health Organization (WHO), the atmospheric

Manuscript received January 14, 2019; revised April 25, 2019. This paper was carried out within and with the support of the scientific researchers of the National Institute for Research and Development in Environmental Protection through the project which is part of Research Program NUCLEU contract 48N/2016 (PN 160401 12), financed by the Romanian Ministry of Research.

The authors are with National Institute for Research and Development in Environmental Protection, 294 Splaiul Independenței, Romania (e-mail: nataliaraischi@yahoo.com). pollution is the cause of death for more than 3.7 million humans annually worldwide [5].

The air quality is mostly affected by total suspended particles (TSP) and particles with a diameter of less than $10 \mu \mathrm{m}\left(\mathrm{PM}_{10}\right)$. The dust dispersion in the air (TSP and $\left.\mathrm{PM}_{10}\right)$ is heavily influenced by weather conditions. According to previous studies, the highest dust concentrations have been measured in the dump area, gradually decreasing with the distance, depending on the wind speed and direction [6]. Drought periods are the greatest hazards, as low air humidity in strong wind conditions favours the resuspension of fugitive dust and the dispersal of pollutants from tailings ponds [7].

The main concern is that fine particles can be inhaled into the human respiratory tract, particles less than $10 \mu \mathrm{m}$ having the greatest chance of reaching the deepest parts of the lungs, leading to a possible negative effect on the exposed population health [8]. Another negative aspect is that the particles transported away from the source through disposition reach the soil and water, generating historical pollution, where, due to the heavy metals content or their compounds, the environmental quality can be affected, especially in view of the fact that some metals have accumulation and persistence properties over time.

\section{MATERIALs AND Methods}

\section{A. Study Area}

The studied area is located in the south-west of Romania, on the left bank of the Danube River and delimited by Locvei Mountains. The influence of the Mediterranean climate makes Moldova Nouă one of the warmest areas in Romania, the disturbing factor being only the strong wind Coşava that blows from the N-E and S-W [9]. The tailings pond from Moldova Nouă, left over from the processing of copper ore, stretches over an area of 130 ha with a height of 20-22.5 m and contains approximately 30 million $\mathrm{m}^{3}$ of sand-like tailings (Fig. 1) [10].

Although the area has tourism potential and biodiversity specific to the Mediterranean climate, the land occupied with industrial waste produces a number of negative effects on the ecosystems in the wetland Divici-Pojejena, included in the RAMSAR site of the Iron Gates Natural Park and implicitly on the rural and urban areas in the immediate vicinity [11]. The tailings pond has been and remains one of the main sources of the environmental factors pollution in the area, because until now, for the two tailings ponds created by the mining activities, no effective greening solutions have been applied. 


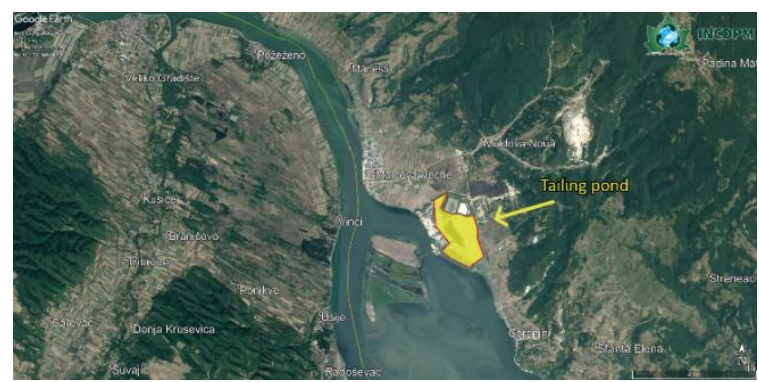

Fig. 1. Location of the tailings ponds from Moldova Nouă.

In the Moldova Nouă area, the National Institute for Research and Development in Environmental Protection (INCDPM Bucharest) has carried out numerous environmental monitoring campaigns to assess the pollution degree produced by tailings dumps/tailings pond present in the study area. Measurement campaigns of environmental quality parameters and sampling for analysis of air dispersion and soil accumulation in tailings were carried out at different times of the year, both in the vicinity of the dumping site and at certain distances from it.

\section{B. Data Analysis Air Quality Monitoring}

The modelling of the atmospheric pollutants dispersion in the area was made taking into account the period of one calendar year (1 January 2016 - 31 December 2016), using the meteorological phenomena database of that period and in-situ monitoring data (the area occupied by tailings ponds and their elevation).

Given the meteorological phenomena of the analysed time frame and the relatively small distance between the tailings ponds and the Serbo-Romanian frontier area, it was considered necessary to study the transport of specific pollutants in order to assess the transboundary pollution degree.

At present, dispersion models have become a primary tool for analysing transport and deposition of pollutants, mainly because an extensive area assessment can be obtained. Consequently, in the present paper, the modelling of dust dispersion in the atmosphere was performed using the AERMOD model have shown that the AERMOD model can be successfully used to analyse the pollutants dispersion in atmospheric air, which is necessary to further identify the most appropriate measures to reduce the impact on air quality in the vicinity of emission sources [12].

According to the U.S. Environmental Protection Agency (US-EPA), in the state of the art, BREEZE AERMOD offers the most complete pollutant dispersion modelling system within $50 \mathrm{~km}$ of the source, being appropriate in the study of emission transport for a variety of sources. In terms of land influence, the software is able to provide modelling for both simple and complex terrain, present situation in the analysed area [13]. The model is widely used for air quality assessment, allowing the supply of isoconcentration curves at different receptors and the assessment of remote pollutant deposition, integrating a variety of sources such as: point, area, volume, line, floating line, open pit, etc. [14].

\section{Location of Air Quality Monitoring Points}

In addition to the study of atmospheric dispersion, in March 2017, in-situ measurements of air quality parameters were realized at certain distances from the tailings pond. The points where the measurements were made are represented in Fig. 2.

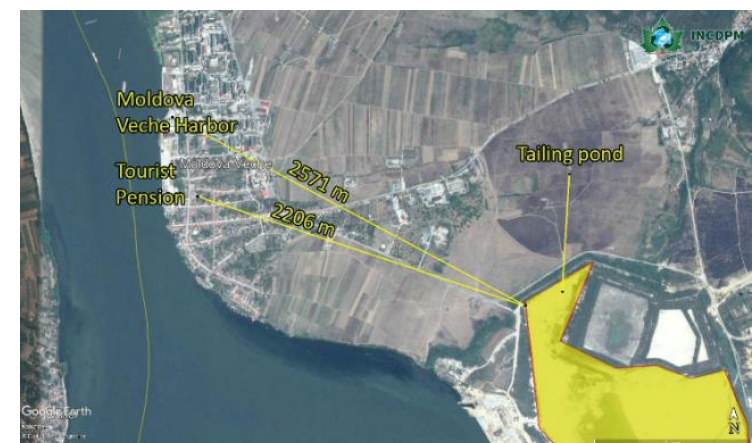

Fig. 2. Distance of monitoring points to the tailings pond in Moldova Nouă

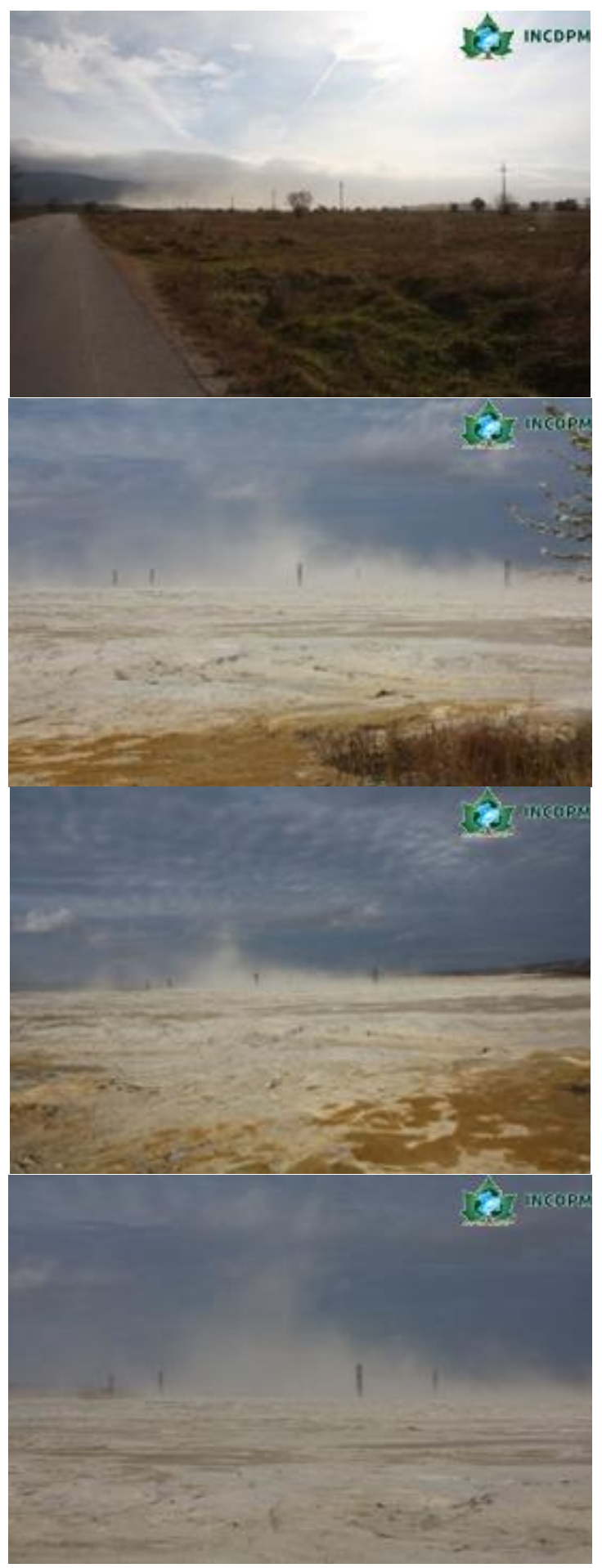

Fig. 3. Dust from tailings ponds from Moldova Nouă, Caras Severin county 
The first monitoring point was chosen at a distance of 2206 $\mathrm{m}$ from the tailings ponds, located in a frequently visited area of locals or tourists, and a second monitoring point was at Moldova Veche Port, located at $2571 \mathrm{~m}$ from the tailings ponds, being considered a tourist attraction of interest, located within the RAMSAR site of the Iron Gates Natural Park. During the measurement campaign, the air quality parameters were monitored with the help of INCDPM Bucharest's mobile auto-lab, which uses, for the acquisition, processing and storage of data, the WinAQMS system that allows the connection of the particle sampling equipment and the monitoring equipment of meteorological parameters (wind speed and direction, relative humidity, temperate air, etc.) for data processing and storage.

Fig. 3 presents images from the tailings ponds perimeter from Moldova Nouă, obtained during the air quality parameters measurement campaign carried out in the area, images where the wind influence on the pollutants dispersion can be seen.

Given the fact that Moldova Nouă area is frequently characterized by unfavourable weather conditions (strong wind), which causes the resuspension of fugitive dust particles from the tailings ponds it was necessary to monitor the particulate matter in $\mathrm{PM}_{10}$ suspension.

\section{AIR QUALITY RESULTS}

Pollution dispersion modelling is a mathematical estimation of the particulate matter emission impact in the analysed area. Using the BREEZE AERMOD, the calculation of the pollutant concentrations is based on equation (1).

$$
C=\frac{Q}{2 \pi u \sigma_{y} \sigma_{z}} \exp \left(-\frac{1}{2}\left(\frac{y}{\sigma_{y}}\right)^{2}\right)\left(\exp -\frac{1}{2}\left(\frac{z-H}{\sigma_{z}}\right)^{2}+\right.
$$

where:

$$
\begin{aligned}
& C=\text { concentration }\left(\mu \mathrm{g} / \mathrm{m}^{3}\right) \\
& Q=\text { emission rate }(\mathrm{g} / \mathrm{s}) \\
& u=\text { wind speed at source }(\mathrm{m} / \mathrm{s}) \\
& \sigma y=\text { coefficient of lateral wind dispersion }(\mathrm{m}) \\
& \sigma z=\text { coefficient of vertical dispersion }(\mathrm{m}) \\
& y=\text { distance of the lateral wind }(\mathrm{m}) \\
& z=\text { height above land }(\mathrm{m}) \\
& H=\text { height of the dispersion at source }(\mathrm{m})
\end{aligned}
$$

For the emission rate estimation for the particular case of the tailings pond, additional determinations were required regarding the tailings content in particles with a diameter of less than $63 \mu \mathrm{m}$, the number of days with precipitation over $0.25 \mathrm{~mm}$ and the wind that registered speeds greater than 5.4 $\mathrm{m} / \mathrm{s}$. [15]. The emission flow, input parameter, required to run the particles dispersion simulation program, was assessed using equation (2) specified in the AP-42 inventory [15].

$$
E F_{T S P\left(\frac{k g}{h a * a n}\right)}=1.9 * \frac{s(\%)}{1.5} * 365 * \frac{365-p}{235} * \frac{f(\%)}{15}
$$

where:

$$
\begin{aligned}
& E F=\text { emission factor } \\
& s=\text { particle content below } 63 \mu \mathrm{m} \text { (silt content) } \\
& p=\text { the number of days with precipitation over } 0.25 \mathrm{~mm} \\
& f=\text { percentage of winds stronger than } 5.4 \mathrm{~m} / \mathrm{s}
\end{aligned}
$$

The percentage of particles with the diameter below $63 \mu \mathrm{m}$ was determined in the laboratory from the samples taken. For this, a granulometric method was used, from which the following particle distribution resulted (Fig. 4):

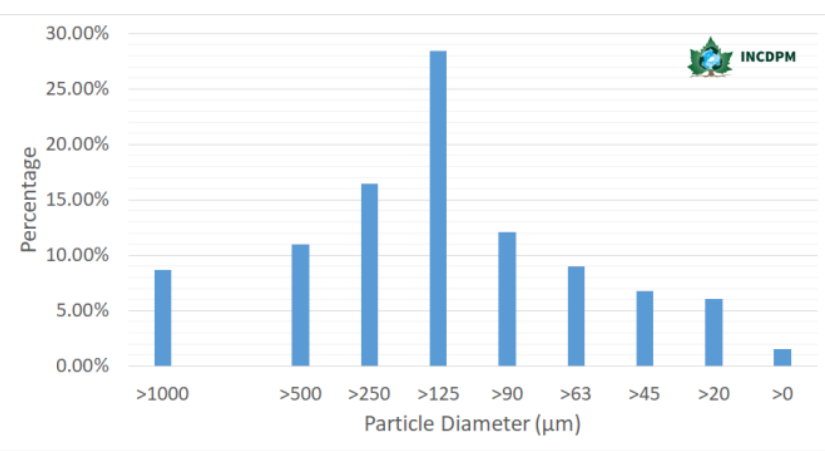

Fig. 4. Particles content in percent.

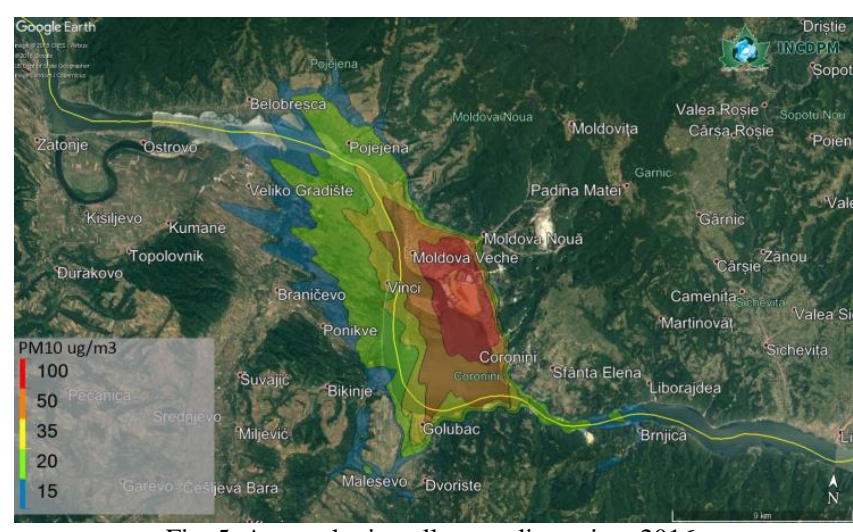

Fig. 5. Atmospheric pollutants dispersion, 2016.

According to the above-mentioned laboratory experiment results, the percentage of particles up to $63 \mu \mathrm{m}$ is $23.43 \%$, representing the solids content transportable in the air mass. To find out the number of days with precipitation over $0.25 \mathrm{~mm}$ specific to 2016 , the database www.rp5.ru, which provided information on the meteorological parameters, was accessed [16]. Thus, for the mentioned period there were recorded 118 days with precipitation values in the considered area. The wind speed of over $5.4 \mathrm{~m} / \mathrm{s}$ was calculated according to the data provided by the meteorological station in Caraş Severin County, which is $7 \%$ for the entire period of 2016.

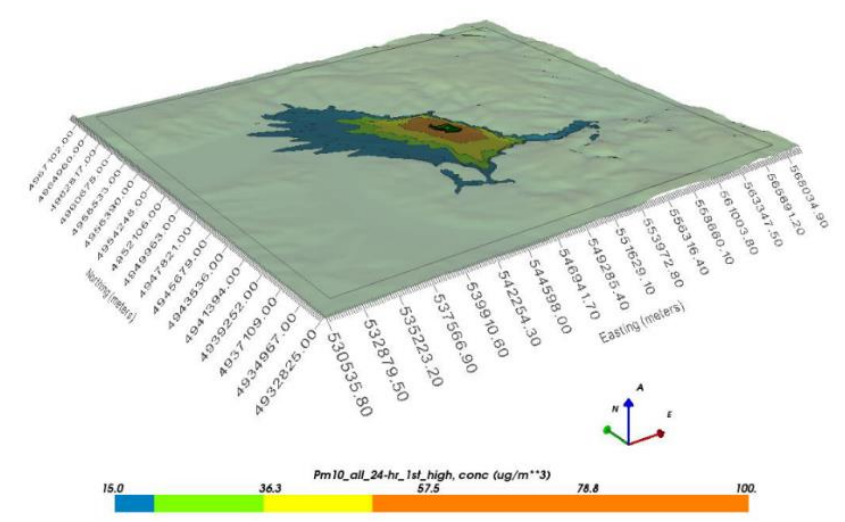

Fig. 6. 3D representation of the pollutant dispersion.

Based on the input data, the atmospheric pollutants dispersion, $\mathrm{PM}_{10}$, was simulated in the area of the tailings pond of Moldova Nouă, shown in Fig. 5. As can be seen from Fig. 5, the pollutants transport is carried out on a large area, 
the most affected villages being Moldova Veche and Coronini on the Romanian side and Vinci on the Serbian side. We point out that these results are based on the average hourly wind speeds recorded by the Caraş Severin weather station cross-border pollution is exacerbated and can affect the RAMSAR site specific ecosystems and implicitly, on the Serbian territory.

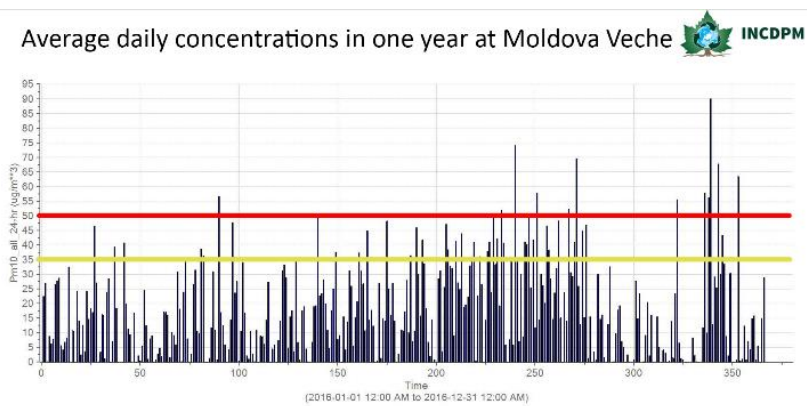

Fig. 7. Distribution of particles concentration of $\mathrm{PM}_{10}(\mu \mathrm{g} / \mathrm{m} 3)$ in Moldova Veche.

The land around the tailings ponds presents certain variations of morphology, which influences the dispersion on certain lateral surfaces, for example predominantly in the eastern direction there was no accentuated pollution, where the natural elevation of the terrain ceases the dispersion of $\mathrm{PM}_{10}$ pollutant (Fig. 6).

The values obtained for the concentrations of $\mathrm{PM}_{10}$ in the air mass, coming from the tailings pond in Moldova Nouă, were critical. The results obtained showed that the daily limit value of $50 \mu \mathrm{g} / \mathrm{m}^{3}$ (24-hour average) was exceeded, according to Law 104/2011, in the tailings ponds area. Fig. 7 shows the daily average concentrations from Moldova Veche village. It is noticeable that there are days when the concentration value exceeds the limit value of $50 \mu \mathrm{g} / \mathrm{m}^{3}$, which indicates that this village is prone to a continuous pollution over the year. From this simulation there can be appreciated a number of 14 days over the year with concentration exceeding the limit value.

The Coronini (Fig. 8) area is not as likely to exceed the limit value of $\mathrm{PM}_{10}$ concentration; however, following the simulation performed, it can be noticed that there are about 19 days per year with concentration over $35 \mu \mathrm{g} / \mathrm{m}^{3}$. This daily concentration value is called the superior evaluation limit and if it is exceeded more than 35 times in a year, then according to the law, the area is under a possible polluting state. Therefore it can be considered that the area may be exposed to the $\mathrm{PM}_{10}$ powders transported from the tailings ponds.

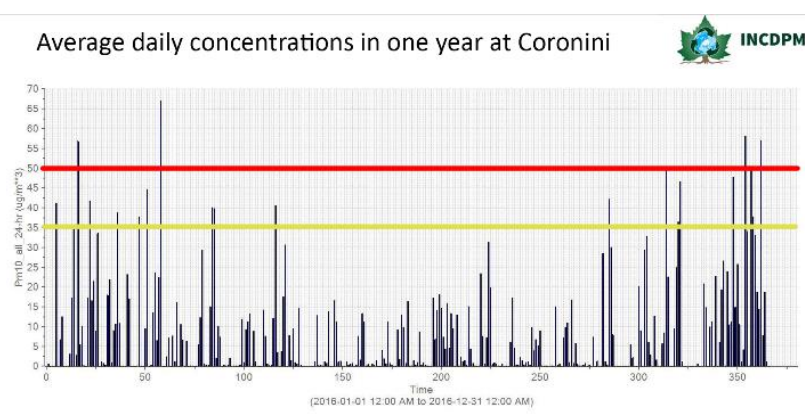

Fig. 8. Distribution of $\mathrm{PM}_{10}$ particles concentration $\left(\mu \mathrm{g} / \mathrm{m}^{3}\right)$ in Coronini.

Regarding Vinci, although the pollutant transport is highlighted, from the dispersion study for the period considered, there were no exceedances of the daily limit value for particulate matter concentrations for the simulated values (Fig. 9).

In the area of interest, Moldova Nouă, a series of local wind phenomena are manifested, favoring the spreading of tailings dust from the tailings pond at Moldova Nouă, namely:

a) The Coșava, which blows on the SE - NV direction, causing significant temperature decreases, with speeds over $20 \mathrm{~m} / \mathrm{s}$;

b) Gorneacul, specific to Moldova Nouă Depression, which blows in the NE - SV direction, with intensities exceeding sometimes $27 \mathrm{~m} / \mathrm{s}$.

Gorneac is responsible for the spreading and transport of tailings from Moldova Nouă tailings ponds over Danube waters to Serbian localities under prolonged drought conditions and lack of vegetation layer [17].

Based on these data, three possible scenarios were realized.

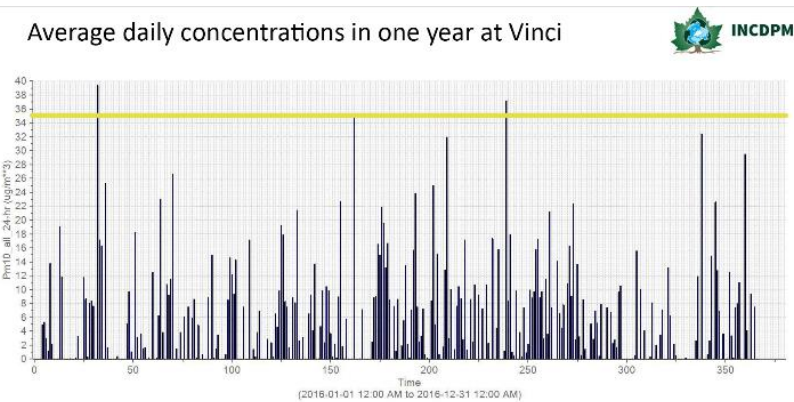

Fig. 9. Distribution of particles concentration of $\mathrm{PM}_{10}\left(\mu \mathrm{g} / \mathrm{m}^{3}\right)$ in Vinci.

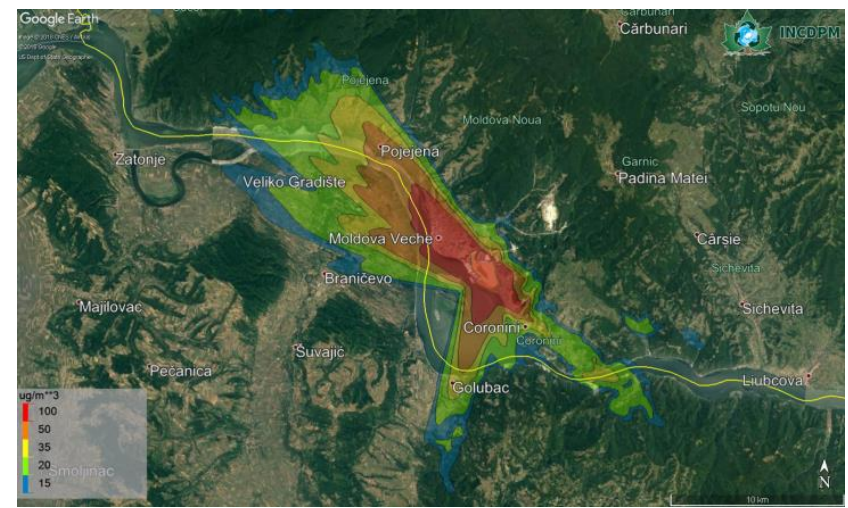

Fig. 10. Scenario simulated for wind speeds between 5 and $10 \mathrm{~m} / \mathrm{s}$.

In Fig. 10, concentrations exceeding the threshold of 50 $\mu \mathrm{g} / \mathrm{m}^{3}$ reach the Pojejena town, which is a city of tourist interest, which would lead to a decrease in the visiting rate and thus a decrease in the city economy, eventually "eliminating" the jobs available in the tourism area. Also, Moldova Veche is an area subject to constant pollution if the wind speed is over $5 \mathrm{~m} / \mathrm{s}$. In the scenario of Fig. 11, it can be noticed that the area with the higher concentration zones is much higher than the one presented above. We can say that wind speed has a major role in transporting suspended particulate matter, noting that in the Pojejena area the concentrations reach more than $100 \mu \mathrm{g} / \mathrm{m}^{3}$, and also the Serbian bank is also subjected to the exceeding the limit of 50 $\mu \mathrm{g} / \mathrm{m}^{3}$, with influence to Veliko Gradiste and Golubac. Given that Veliko Gradiste is a large area of tourism, the tailings pond can have a negative impact on the local economy and on the population health established there or in transit as it can 
be subjected to several acute exposure with powders pollution. This scenario also shows that the wetland Divici-Pojejena can be polluted by these particulates transported from the tailings pond, which negatively influences the ecosystem present there.

In all scenarios, it can be observed that the pollution follows two main directions, namely the SE-NV direction, which is specific to the Coşava, and the NE-SV direction, specific to Gorneac.

In Fig. 12, the deposition tendency of tailings ponds dust resulting from the erosion of the dump at winds over $5.4 \mathrm{~m} / \mathrm{s}$ can be noticed.

Most of the particulates are deposited near the tailings ponds, but in the direction of SE-NV, there is a high tendency of dust transport due to the Coşava that blows predominantly in this direction and for a longer period than Gorneac.

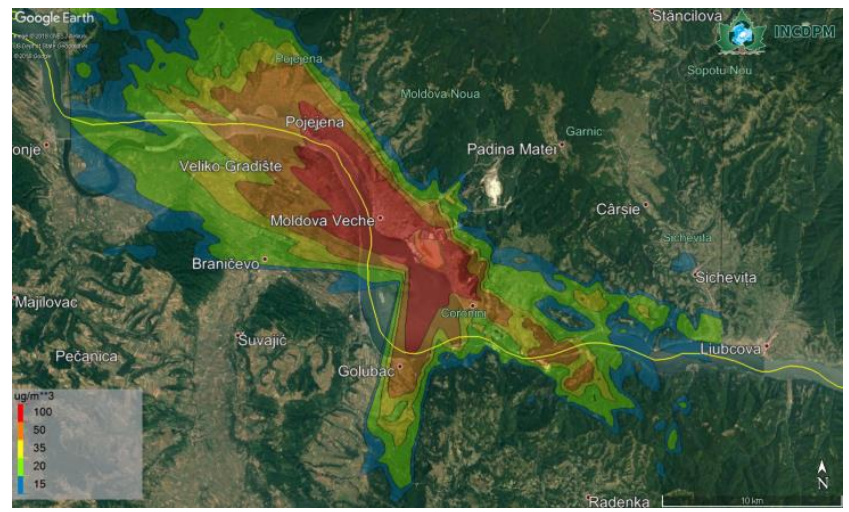

Fig. 11. Simulated scenario for wind speeds between 10 and $20 \mathrm{~m} / \mathrm{s}$.

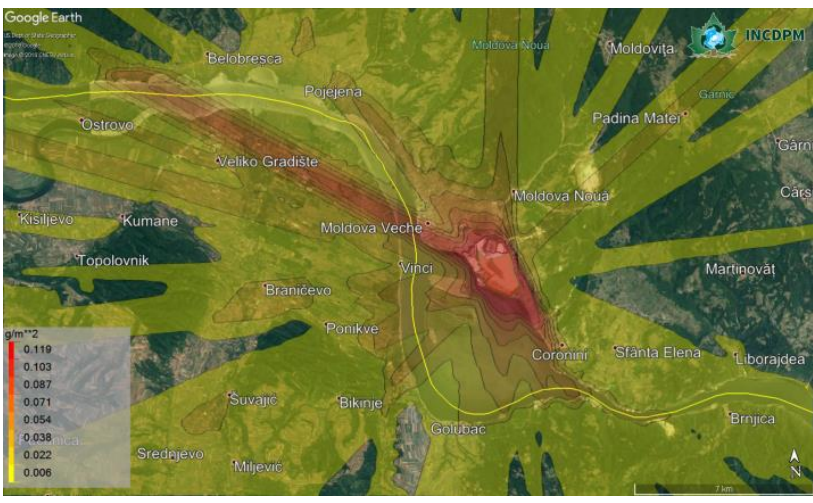

Fig. 12. Particles deposition tendency.

As a result of the $\mathrm{PM}_{10}$ concentrations measurement, carried out with the Mobile laboratory from the INCDPM, in the two monitoring points described above Fig. 2, the graphs resulted are shown in Fig. 13-18. At the first point, monitoring was carried out on 21 and 23 March 2017 under different weather conditions. As can be seen in Fig. 13, in the hour range $00.00-09.00,21.03 .2017$, the wind speed recorded the most values between $1.5-2 \mathrm{~m} / \mathrm{s}$, the wind direction being from the NW to SE, respectively from the monitoring area to the tailings ponds. Within this range, the concentration of suspended particles in the monitored area did not exceed the daily limit value set by Law 104/2015, as can be seen in Fig. 14.

At the same point, on 23.03.2017, during the time 00:00-10:00, the wind direction was from S and SE (Fig. 15). In addition, the wind speed during this period was much higher than in the previous period, with a significant number of values exceeding $4 \mathrm{~m} / \mathrm{s}$. In this case, in the Moldova Veche area, exceedance of concentrations of $\mathrm{PM}_{10}$ in the monitored interval was recorded at the monitoring point more than $2 \mathrm{~km}$ from the tailings ponds, when the wind direction was predominantly from the tailings ponds to the monitored area (Fig. 16).

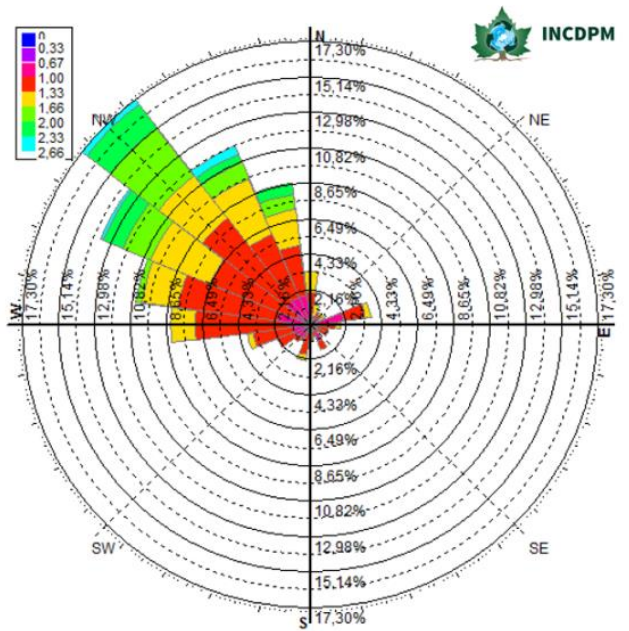

Fig. 13. Wind rose during 21.03.2017, at the monitoring point I.

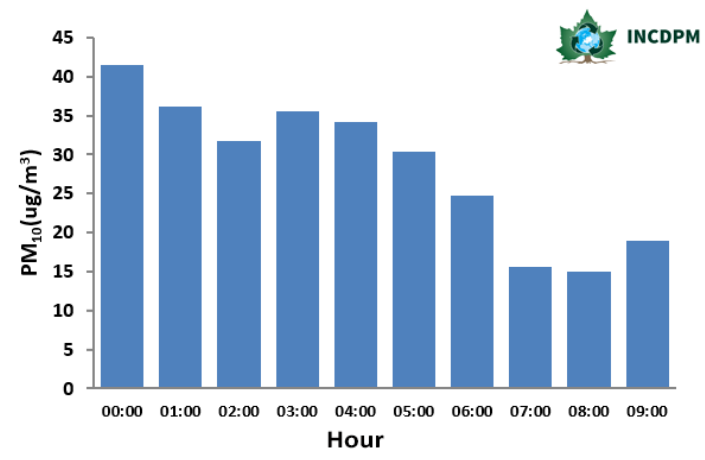

Fig. 14. $\mathrm{PM}_{10}$ concentration measured in the Moldova Veche area on 21.03.2017.

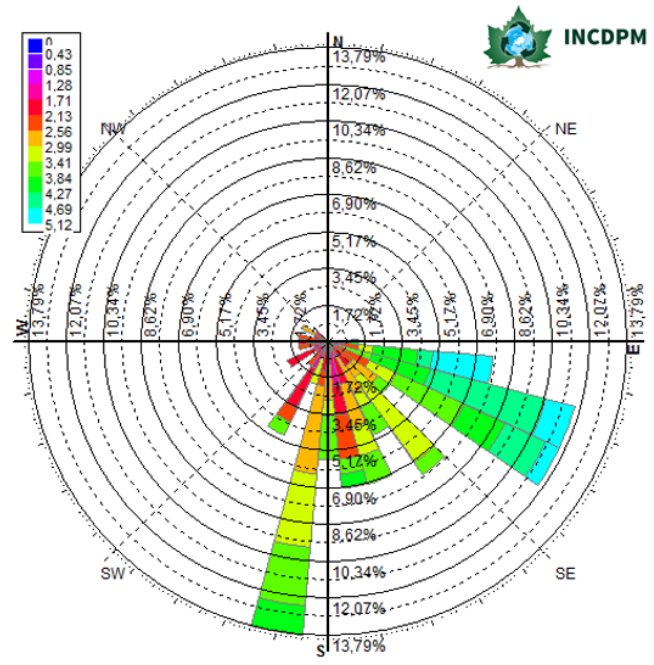

Fig. 15. Wind rose during 23.03.2017, at the monitoring point I

The second area analysed in the monitoring campaign was the harbor of Moldova Veche, an interest tourist area, about $2570 \mathrm{~m}$ from the tailings pond in the NW direction. In the monitoring range although the wind speed recorded the most values between $4.5-5 \mathrm{~m} / \mathrm{s}$, the wind blowing from the dump to the port, no exceedances of the $\mathrm{PM}_{10}$ limit concentration were recorded in the monitoring area. In this case, the 
dispersion is influenced by the interaction with constructions located on the wind direction. The data obtained are shown in Fig. 17 and Fig. 18.

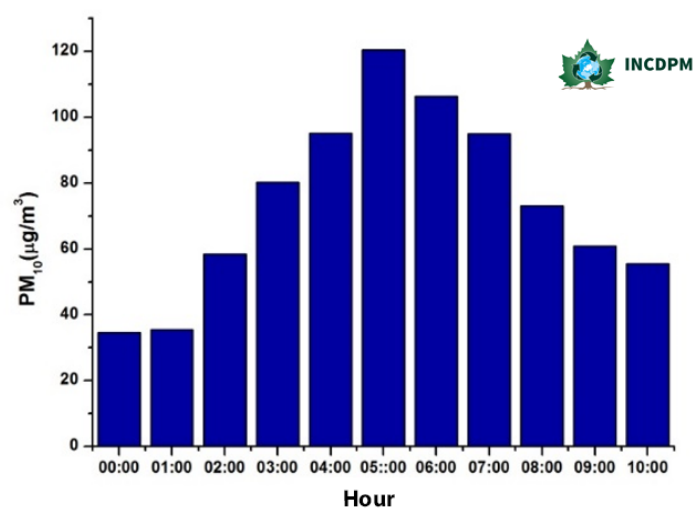

Fig. 16. $\mathrm{PM}_{10}$ concentration measured in the Moldova Veche area on 23.03.2017.

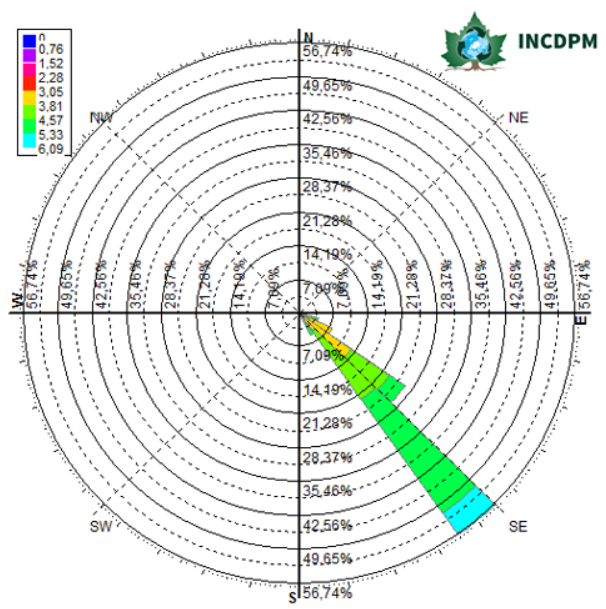

Fig. 17. Wind rose during 23.03.2017 at the monitoring point II.

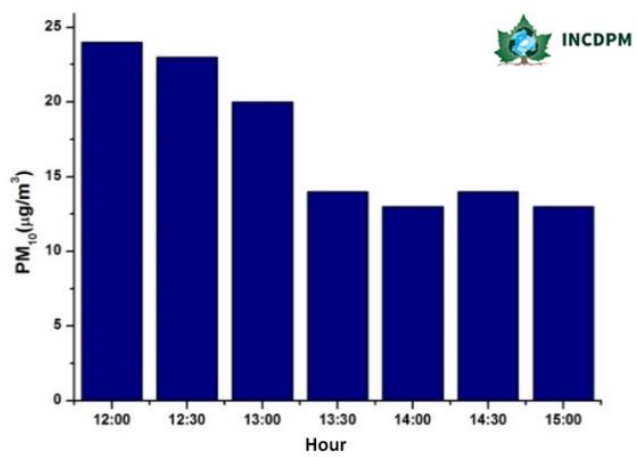

Fig. 18. $\mathrm{PM}_{10}$ concentration measured in the port of Moldova Veche city on 23.03.2017.

\section{DATA ANALYSIS. SOIL DUST MONITORING}

In order to analyse the environmental factors, INCDPM conducted additional field investigations, this time was the quantitative and qualitative analysis of the dust deposited on the soil over time, researches necessary to study the tailings pond impact on the Iron Gates Natural Park - Divici-Pojejena Wetland [11].

\section{A. Location of Sampling Points of Dust Deposited on the Soil over Time}

Soil samples were taken from Baziaş - Moldova Nouă area, from 8 points, presented in Fig. 19 and Table I.
TABLE I: ID'S OF SAMPLE POINTS

\begin{tabular}{cc}
\hline \hline Location & Sample Code \\
\hline FIRST CAMPAIGN (25.06.2014) & \\
\hline Baziaş & C1SZ1P1 \\
\hline Şuşca & C1SZ2P2 \\
\hline Pojejena Port - recreation & C1SZ2P3 \\
\hline Pojejena Port - Purification Station shore & C1SZ2P4 \\
\hline Confluence Pojejena - Danube & C1SZ2P5 \\
\hline $\begin{array}{c}\text { Măceşti - location 1 - (next to the holiday } \\
\text { home) }\end{array}$ & C1SZ3P6 \\
\hline Măceşti - location 1 (shore) & C1SZ3P7 \\
\hline Moldova Nouă Port & C1SZ3P8
\end{tabular}

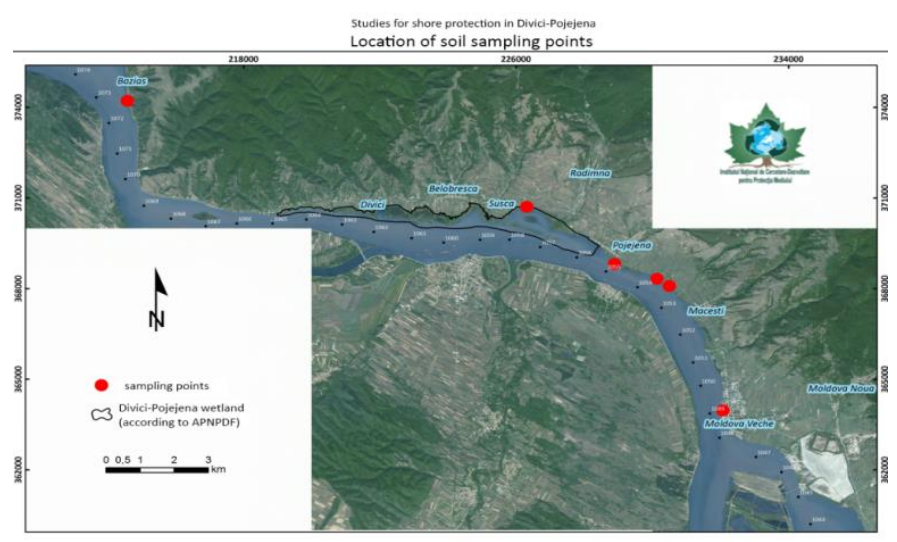

Fig. 19. Location of soil sampling points.

\section{B. Soil Quality Results}

The results of the physico-chemical analyses for the samples taken are shown in Fig. 20 and in Table II are the values of the alert and intervention thresholds for sensitive/less sensitive uses set out in the Regulation on Environmental Pollution Assessment of Ord. 756/1997.

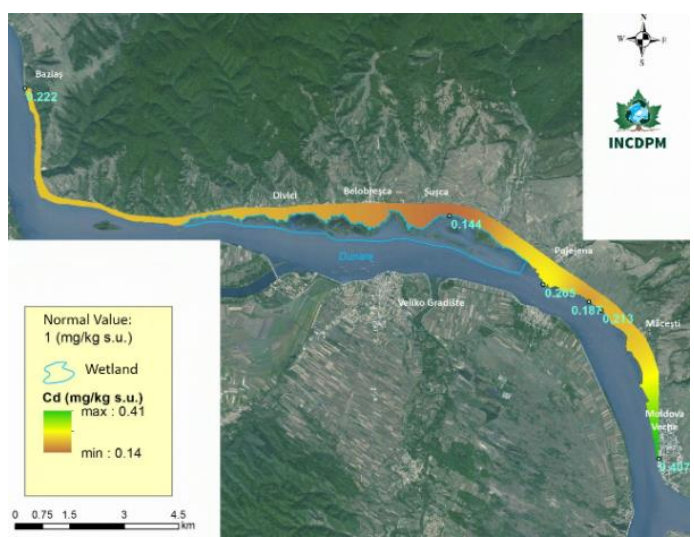

Distribution of Cadmium concentration ( $\mathrm{mg} / \mathrm{kg}$ ) from soil, Baziaş - Moldova Nouă area (a)

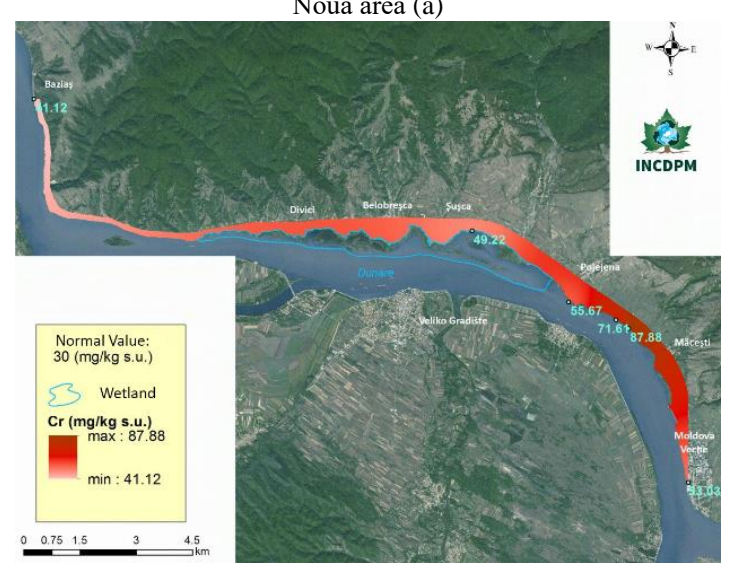

Distribution of Chromium concentration $(\mathrm{mg} / \mathrm{kg})$ from soil, Bazias Moldova Nouă area (b) 


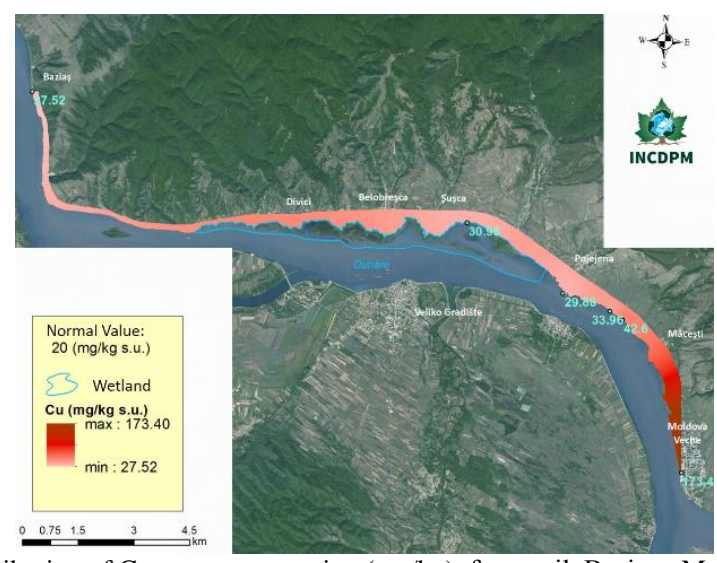

Distribution of Copper concentration (mg/kg) from soil, Baziaş - Moldova

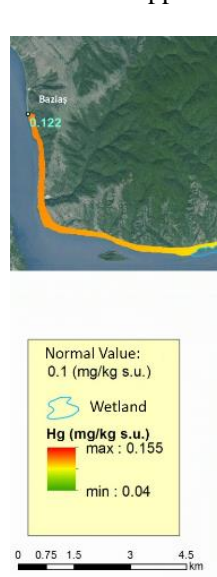
Nouă area $(\mathrm{c})$

Distribution of Mercury concentration $(\mathrm{mg} / \mathrm{kg})$ from soil, Baziaş - Moldova Nouă area (d)

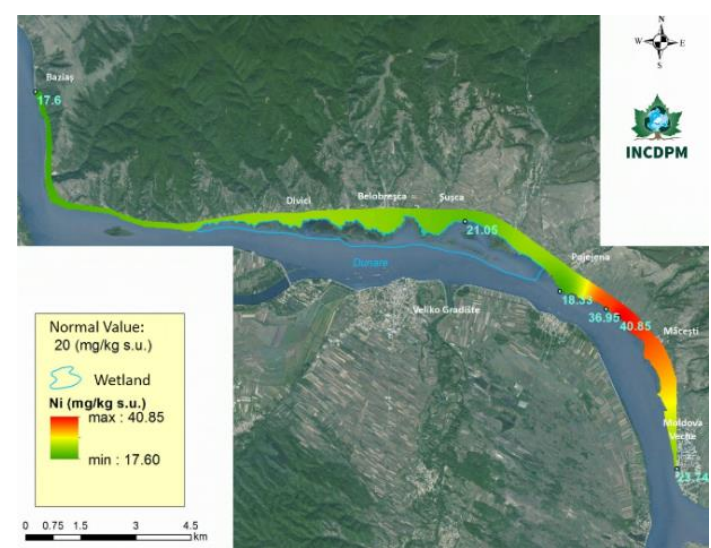

Distribution of Nickel concentration $(\mathrm{mg} / \mathrm{kg})$ from soil, Baziaş - Moldova

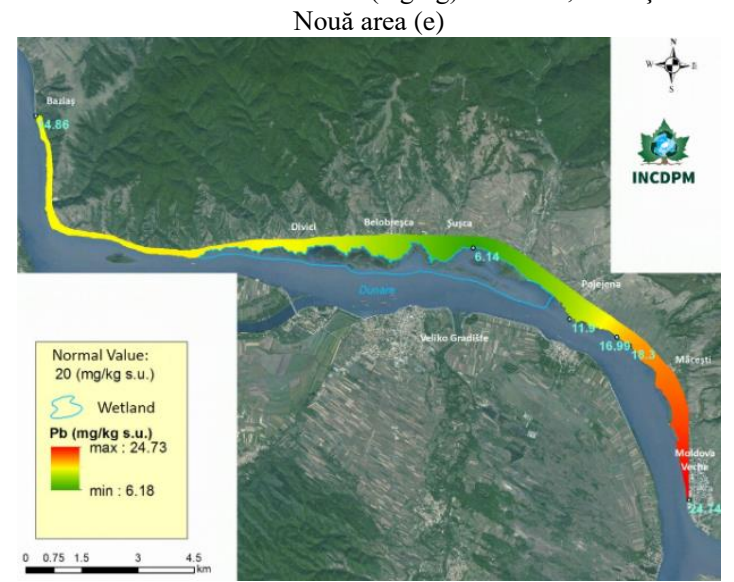

Distribution of Lead concentration $(\mathrm{mg} / \mathrm{kg}$ ) from soil, Baziaş - Moldova Nouă area (f)

Fig. 20. Distribution of the pollutants concentration from the samples collected from Baziaş - Moldova Nouă area.

TABLE II: REFERENCE VALUES ACCORDING TO ORDER 756/1997

\begin{tabular}{|c|c|c|c|c|c|c|c|c|}
\hline \multirow{7}{*}{ 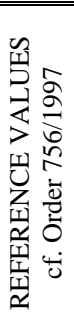 } & \multicolumn{2}{|c|}{ Parameter } & Cadmium & Copper & Chromium & Mercury & Nickel & Lead \\
\hline & & & \multicolumn{6}{|c|}{ (mg/kg d.s.) } \\
\hline & \multicolumn{2}{|c|}{ Normal values } & 1 & 20 & 30 & 0.1 & 20 & 20 \\
\hline & \multirow{2}{*}{$\begin{array}{l}\text { Alert thresholds / } \\
\text { Types of uses }\end{array}$} & Sensible & 3 & 100 & 100 & 1 & 75 & 50 \\
\hline & & Less sensible & 5 & 250 & 300 & 4 & 200 & 250 \\
\hline & \multirow{2}{*}{$\begin{array}{l}\text { Thresholds for } \\
\text { intervention / } \\
\text { Types of uses }\end{array}$} & Sensible & 5 & 200 & 300 & 2 & 150 & 100 \\
\hline & & Less sensible & 10 & 500 & 600 & 10 & 500 & 1000 \\
\hline
\end{tabular}

The results of the physico-chemical analyses of dust samples showed the following:

- $\mathrm{pH}$ of the soil in samples ranges from neutral to slightly basic, respectively $\mathrm{pH} 7,45$ (C1SZ3P6) to $\mathrm{pH}$ 8,08 (C1SZ2P2);

- Copper concentration values are between 12.20 and $173.4 \mathrm{mg} / \mathrm{kg}$; the maximum concentrations for copper $(173.4 \mathrm{mg} / \mathrm{kg} \mathrm{s.u})$ were determined at sample s.u., C1SZ3P8, located nearest to the tailings ponds of Moldova Nouă;

- Cadmium content for all analysed soil samples is below the normal soil concentration, the maximum concentration determined was $0,407 \mathrm{mg} / \mathrm{kg}$ s.u. (C1SZ3P8);

- Maximum concentrations determined for chromium, lead, mercury and nickel were observed for C1SZ1P1 samples (lead - $24.74 \mathrm{mg} / \mathrm{kg}$ s.u.), C1SZ2P2 (mercury - $0.155 \mathrm{mg} / \mathrm{kg} \quad$ s.u.) and C1SZ2P3 (chromium - $87.88 \mathrm{mg} / \mathrm{kg}$ and nickel $-40.85 \mathrm{mg} / \mathrm{kg}$ s.u.), samples located near the tailings ponds of
Moldova Nouă

\section{CONCLUSIONS}

The results of this paper were obtained by analysing the environmental pollution level from dust deposited on the soil over time, coming from the tailings dump/tailings pond near Moldova Nouă. Usually, the atmospheric conditions and the meteorological parameters contribute to the pollutants formation and dispersion [18].

Concerning air quality, it could be appreciated that it exists exceedances of the daily limit values for $\mathrm{PM}_{10}$ concentrations in the areas adjacent to the surface source according to Law 104/2008 (Directive 2008/50/EC ambient air quality and cleaner air for Europe) to the parameters used for simulation. Thus, under certain meteorological conditions, the average daily concentrations of $\mathrm{PM}_{10}$ have exceeded the limit value of $50 \mu \mathrm{g} / \mathrm{m}^{3}$ in the Moldova Veche and Coronini areas.

According to model results, the map shows an area prone to $\mathrm{PM}_{10}$ pollution, to a lesser extent, in the cross-border zone, 
in Vinci town of Serbian area. In this area, given the annual wind speed average of about $20 \mathrm{~km} / \mathrm{h}$, the daily $\mathrm{PM}_{10}$ concentrations average do not exceed the limit value according to the Directive mentioned above. However, given that the pollutants transport is predominantly to the NW, it can be estimated that under certain meteorological conditions (during storms, when wind speeds exceeding $60 \mathrm{~km} / \mathrm{h}$ ), cross-border pollution is increasing and can affect Serbian territory, implicitly the ecosystems specific to the site of international importance RAMSAR.

Also, was conducted the in-situ measurements of the air quality parameters, carried out with the air monitoring auto-lab help, made at two fixed points located at distances of more than $2 \mathrm{~km}$ from the source of pollution. The measurements resulted for particulate matter $\left(\mathrm{PM}_{10}\right)$, shows daily average concentrations values in ambient air exceed, under certain weather conditions, the limit value of $50 \mu \mathrm{g} / \mathrm{m}^{3}$. Although the measurements were made in short intervals, by interpreting the results presented in the previous graphs, it was possible to ascertain the direct influence of the emissions from the tailings ponds on the village of Moldova Veche, implicitly, the risk of cross-border pollution, in certain weather conditions.

The results of this paper shows that there is a real risk of air pollution in the area adjacent to the tailings dump, which according to WHO can have a negative impact on the exposed population health, especially in the case of persons with different diseases of the respiratory system. Following the scenarios made using the AERMOD modelling software, there is a major risk of cross-border pollution with $\mathrm{PM}_{10}$ powders.

The main disadvantage of this method to estimate pollutant dispersion using models is that they are prone to errors, depending on the source type, distance (this model only works best on short distances, maximum $50 \mathrm{~km}$ ), meteorological conditions and input data. In addition, the dispersion maps presented are a worst-case scenario that means it is almost impossible to reach that kind of pollution over such a large area in one day. However, using the model and in-situ monitoring systems, we could very well appreciate if the model is accurate or not. It is a great method for confirming that the values calculated by the model are consistent with the real life concentration values.

Regarding the quality of soil dust deposited over time, eight samples from the sector between Baziaş and Moldova Nouă were analysed. X-ray fluorescence analyses performed on samples taken showed the presence of heavy metals $(\mathrm{Cd}$, $\mathrm{Cr}, \mathrm{Cu}, \mathrm{Hg}, \mathrm{Ni}, \mathrm{Pb})$. Thus, the results revealed the influence of historical pollution caused by the presence of tailings ponds on soil quality in the analysed area.

It can be emphasized that in the area of Moldova Nouă, the frequency and intensity of the Coşava wind is appreciable and the tailings ponds are a main source of pollution for the neighbouring lands, which is also evidenced by the soil dust samples results analysed, deposited in time in area. In this context, this source of pollution poses a risk to the site of community importance RAMSAR and implicitly has a cross-border impact, which emphasizes the need to implement preventive measures. Such a preventive measure of the pollution source is the urgent adoption of a greening solution for the tailings ponds while eliminating the possibility of the Danube pollution by rainwater.

\section{REFERENCES}

[1] C. Y. Wright, M. Matooane, M. A. Oosthuizen, and N. Phala, "Risk perceptions of dust and its impacts among communities living in a mining area of the Witwatersrand, South Africa," Clean Air Journal, vol. 24, no. 1 June 2014.

[2] S. A. Abdul-Wahab and F. A. Marikar, "The environmental impact of gold mines: Pollution by heavy metals," Cent. Eur. J. Eng., vol. 2, no. 2, 2012, pp. 304-313.

[3] A.-M. Resetar-Deac and E. Diacu, "Assessment of aquatic environment contamination with heavy metals from abandoned mines of Northwestern Romania," REV. CHIM, vol. 66, no. 9, 2015.

[4] O. Oguntoke, M. E. Ojelede, and H. J. Annegarn, "Frequency of mine dust episodes and the influence of meteorological parameters on the Witwatersrand area, South Africa," Hindawi Publishing Corporation International Journal of Atmospheric Sciences Volume 2013, Article ID 128463, p. 10.

[5] World Health Organization. 7 million premature deaths annually linked to air pollution. [Online]. Available: http://www.who.int/mediacentre/news/releases/2014/air-pollution/en/

[6] N. Lilic, A. Cvjetic et al., "Dust and noise environmental impact assessment and control in Serbian mining practice," Minerals, 2018, vol. 8 , no. 2 , p. 34 .

[7] I. F. Burlacu et al., "Greening solutions applicable in the tailing ponds Tăusani and Bosneag from Moldova Nouă," IOP Conf. Series: Materials Science and Engineering, 2017.

[8] S. N. Raischi et al., "Air pollution analysis in Moldova Nouă waste dump," ECOTERRA - Journal of Environmental Research and Protection.

[9] G. Rogobete et al., "Politehnica" din Timişoara Oficiul de Studii Pedologice şi Agrochimice Timişoara, Entiantrosolurile din zona haldelor de la Moldova Nouă județul Caraş-Severin," Soil Forming Factors and Processes from the Temperate Zone, vol. 4, 2005, pp. 87-92.

[10] F. Popescu, "A performant state-of-art tool to assess cross-border impact of industrial activities. A transboundary air pollution case study," Procedia Technology, vol. 22, 2016, pp. 440-444.

[11] D. György et al., "Studii de teren - investigații pentru cuantificarea parametrilor biotici și abiotici referitori la habitate și biodiversitate," INCDPM București, 2014.

[12] N. Lilic et al., "Dust dispersion modeling for an opencast coal mining area," Tehnika, 2012, vol. 6, pp. 911-918.

[13] Users guide for the aermod terrain preprocessor (AERMAP), EPA-454/B-03-003, October 2004.

[14] Air model data. [Online]. Available: http://breeze-software.com/

[15] Australian Government, National Pollutant Inventory Emission Estimation Technique Manual for Mining Version 3.1, 2012.

[16] Weather for 243 countries. [Online]. Available: https://rp5.ru/

[17] R. N. P. Romsilva, "Management plan," Administration of the Portile de Fier Natural Park R.A.

[18] R. Szep, R. Keresztes et al., "Study of air pollution and atmospheric stability in Ciuc Basin - Romania," Revista de Chimie, vol. 68, no. 8, 2017, pp. 1763-1767.

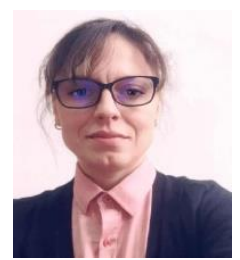

E. Simona Natalia Raischi was born in Bucharest, Romania, on July 22, 1978. She was PhD student, University Politehnica Bucharest, the bachelor degree and master degree, energy and environmental engineering, University Politehnica Bucharest.

She currently works as a scientific researcher and head of the engineering for Environmental Protection and Impact Assessment Department at the National Institute for Research and Development in Environmental Protection INCDPM, Bucharest, Romania.

Eng. Rasichi's projects related to the article: Elaboration of the studyGreenhouse gas emissions reduction in case of usage alternatives fuels to replace conventional ones, Research on estimating emissions from urban traffic PN 16040112.2 (2017), Research on improving the estimation of emissions from surface sources PN 160401 12.1 (2017), beneficiary Romanian Ministry of Innovation and Research.

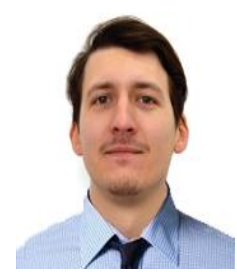

Pană Eduard Costin was born in Bucharest, Romania, on November 13, 1993. He was PhD. Student at University Politehnica Bucharest, 2018-present, Faculty of Material Science and Engineering, the master's degree at University POLITEHNICA Bucharest, 2016-2018, Faculty of Material Science and Engineering, specialization "environmental protection in industry of metallic 
materials", the bachelor's degree at University Politehnica Bucharest, 2012-2016, Faculty of Material Science and Engineering, specialization "engineering and environmental protection in industry".

$\mathrm{He}$ is a junior scientific researcher in the Natural and Technological Hazards Department at the National Institute for Research and Development in Environmental Protection - INCDPM, Bucharest, Romania, since 2016.

Eng. Pană's projects related to the article: Research on estimating emissions from urban traffic PN 16040112.2 (2017), Research on improving the estimation of emissions from surface sources PN 160401 12.1 (2017), Research on identifying the most appropriate methods for reducing pollution in vulnerable areas PN 18260103.2 (2018), beneficiary Romanian Ministry of Innovation and Research.

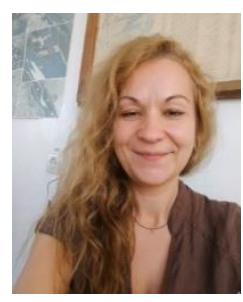

Elena Holban was born in Olteniţa, Romania 1979 She got the PhD degree in chemistry, University Politehnica Bucharest, the master's Degree in environmental protection, University of Bucharest. She works as a senior researcher and head of the Biodiversity and Ecosystem Dynamics Department at the National Institute for Research and Development in Environmental Protection, INCDPM, Bucharest, Romania and has more than 15 years of experience in the field of environmental protection as a Scientific Researcher, in biodiversity conservation studies.

Holban through her experience in the field of environmental protection she participated as an expert in many environmental monitoring projects of national and international importance such as: Research on estimating emissions from urban traffic PN 16040112.2 (2017), Research on improving the estimation of emissions from surface sources PN 160401 12.1 (2017), Research on identifying the most appropriate methods for reducing pollution in vulnerable areas PN 18260103.2 (2018), beneficiary Romanian Ministry of Innovation and Research.

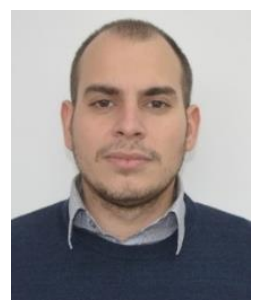

Adrian-Ştefan Zamfir was born in Rm. Valcea, Romania, on May 05, 1990. He was PhD student, 2015-present "Dunărea de Jos" University of Galați, the master degree: biotechnology for environmental protection, 2013 - 2015 University of Agronomic Sciences and Veterinary Medicine Bucharest, the bachelor degree: Engineer in agrotourism and public catering, 2009 - 2013 University of Agronomic Sciences and Veterinary Medicine Bucharest, bachelor degree: engineer in agrotourism and public catering.

$\mathrm{He}$ is a scientific researcher in the Natural and Technological Hazards Department at the National Institute for Research and Development in Environmental Protection, Bucharest.

Eng. Zamfir's projects related to the article: Research on estimating emissions from urban traffic PN 16040112.2 (2017), Research on improving the estimation of emissions from surface sources PN 160401 12.1 (2017), Research on identifying the most appropriate methods for reducing pollution in vulnerable areas PN 18260103.2 (2018), beneficiary Romanian Ministry of Innovation and Research.

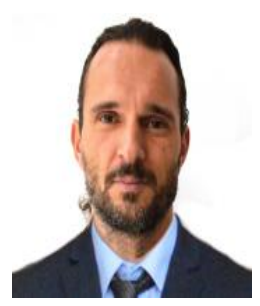

Constantin Marius Raischi was born in Bucharest, Romania,on September 08, 1976. He was PhD student - "Dunărea de Jos" University, Galați, Industrial Engineering / Aquaculture and Fisheries, the master degree - University Politehnica of Bucharest - Natural Resources and Environment Economy Management, the bachelor degree - the Bucharest University of Economic Studies.

$\mathrm{He}$ is employed as a senior researcher and head of
Technological and Natural Hazards Department at the National Institute for Research and Development in Environmental Protection, Bucharest, Romania.

Mr. Raischi's projects related to the article: Research on estimating emissions from urban traffic PN 16040112.2 (2017), Research on improving the estimation of emissions from surface sources PN 160401 12.1 (2017), Research on identifying the most appropriate methods for reducing pollution in vulnerable areas PN 18260103.2 (2018), beneficiary Romanian Ministry of Innovation and Research.

Selective Patents and Awards:

- Patent no. 129803 / Mobile station of type DKMR-01T by remote sensing monitoring of ihtiofauna and especially of sturgeons in difficult hydrological conditions, awarded with 20 prizes of excellence / specials and platinum, gold and silver medals at the International Inventions Salons (Cluj Napoca, Iasi, Timisoara - Romania, Geneva - Switzerland, Toronto - Canada, Zagreb - Croatia, Warsaw - Poland, London - UK, Bangkok-Thailand, Barcelona-Spain)

A / 00773 The DKTB monitoring station of the ichthyofauna and especially of the sturgeons, by ultrasonic remote sensing under different hydrological conditions (under evaluation), awarded with 15 excellence / special prizes and gold and silver medals at the Salons of International Inventions (Brussels - Belgium, Cluj - Napoca, Iasi, Timisoara - Romania, Toronto - Canada, Zagreb - Croatia, Warsaw - Poland, London - UK, Bangkok - Thailand, Geneva-Switzerland)

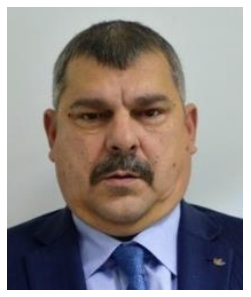

Deák György was born in Gheorgheni, Romania, on Feb. 27, 1966. He got the doctoral studies in environmental engineering (Order No. $3387 / 22.03 .2018$ of the Ministry of Education), Affiliation at the Politehnica University of Bucharest; Senior Researcher degree from 2008 (Order No. 3767/18.04.2008 of the Ministry of Research and Education); PhD title obtained in 2003, University of Petrosani. He is general director and President of the Administrative Council of National Institute for Research and Development in Environmental Protection (INCDPM) (Order No. 1144/26.07.2010 of the Ministry of Education). He also is Member of Scientific Council of Danube Delta Biosphere Reserve Authority, 2011-prezent, (Updated Order No. 1521/29.09.2015 of Ministry of Environment, Water and Forests). He published 6 patents and participated at many innovation events where he was awarded with over 100 medals of gold, silver and platinum.

Selective Publications:

1) Good Practice Guide on Wetlands Ecosystems Mapping and Assessment, Monica Matei, Lucian Laslo, DEÁK György, Nicu Ciobotaru, Madalina Boboc, Marius Raischi, Cristina Musat, Theodor Lupei, Simona Raischi, Andreea Moncea, Diana Dumitru, Gabriel Badea, Lampros Lamprinakis, Gracia P. Rodriguez, Anne Strøm Prestvik, Asbjorn Veidal, Bjørn Klimek, Universitas Petrosani, ISBN 978-973-741-533-2, 2017.

2) Dry Deposition of the PM 10 and PM 2.5 to the Vegetationand its Health Effect in the Ciuc Basin, Robert Szep, Reka Keresztes, DEÁK György, Francisc Toba, Marieta Ghimpusan, Revista de Chimie -Bucharest- Original Edition- 67(4):639-644, April 2016.

Eng. Deák György, PhD. Habil. projects related to the article: Research on estimating emissions from urban traffic PN 160401 12. 2 (2017), research on improving the estimation of emissions from surface sources PN 160401 12. 1 (2017), research on identifying the most appropriate methods for reducing pollution in vulnerable areas PN 18260103.2 (2018), beneficiary Romanian Ministry of Innovation and Research. 